\title{
IMPLEMENTATION OF ENTERPRENEURSHIP, BUYING AND SELLING ACTIVITIES IN MATHEMATICS LEARNING TO PROMOTE STUDENTS INTERACTION AND METACOGNITIVE REGULATION SKILLS
}

\author{
MOHAMAD ARIFFIN ABU BAKAR* AND NORULHUDA ISMAIL \\ School of Education, Faculty of Social Sciences and Humanities, Universiti Teknologi Malaysia, Johor, Malaysia. \\ *Corresponding author: mohamadariffin6299@gmail.com \\ Submitted final draft: 18 November 2019 Accepted: 2 January $2020 \quad$ http://doi.org/10.46754/jssm.2020.07.013
}

\begin{abstract}
Metacognitive regulation skills and interaction are interrelated elements in mathematics learning to enhance the engagement and focus of the students. Interactions will affect the development of metacognitive regulation skills. Metacognitive regulation skills will ensure students' mathematics problem solving is well managed to provide an accurate solution. One of the factors contributing to weak mastery of mathematics among students is learning activities do not ensure optimal interaction. Therefore, initiatives need to be implemented to address the problems. So, the present study will propose, summarise and discuss the implementation of entrepreneurship, buying and selling as an activity that can encourage students to interact and develop as well as to train their metacognitive regulation skills. Articles around 2009 and up to date have been explored based on approaches, methods, techniques, and practices of entrepreneurship learning strategies implemented. A total of 8 articles were selected through a search of databases such as Google Scholar, Researchgate, ERIC, SpringerLink, Elsevier and more. Systematic reviews and discussions through previous research show that the effectiveness of the implementation of buying and selling activities in mathematics learning is creating interaction and leading to increased student metacognitive regulation skills.
\end{abstract}

Keywords: Metacognitive regulation, interaction, entrepreneurship, buying selling, mathematical learning.

\section{Introduction}

Mathematics learning is a process for changing the coordination of thought, which is to explain something abstract and to link numbers, symbols, shapes, patterns and so on to form a real concept. Chris (2015) stated that mathematical learning is not only focused on telling but also requires strengthening to enhance individual intellectual credibility. Therefore, the teacher needs to change the learning approach from conventional methods as a presenter to learning agents who are seen to be more widespread for providers, drivers, facilitators and coordinators to learn. Learning materials are not entirely on the teacher, but students are also learning resources for other students (Pokhrel, 2018). This learning transformation requires teachers to manage to learn more effectively. Students should also become managers of self-study more systematically and efficiently.
To improve learning management efficiency, metacognitive regulation is a positive indicator that will ensure students become active during the learning process. Metacognitive regulation is a component of metacognition that is according to Schraw and Moshman (1995) the ability of the individual to regulate their cognition by controlling, monitoring and acting systematically. Subcomponents in metacognitive regulation are constructs that demonstrate the process of new knowledge development (Schraw \& Moshman, 1995; Hasbullah, 2015). Through planning constructs, students will set learning goals, set up the way how to achieve the goals and know the previous knowledge to be used (Moos \& Ringdal, 2012). Construct monitoring will ensure that students are always aware of the level of understanding, strategies used, reducing mistakes, confirming the knowledge to be developed is the right concept (Stephanou \& Mpiontini, 2017). 
Moreover, the evaluation construct will help students build confidence with new knowledge, test the effectiveness of the strategies used and evaluate the strength of knowledge (Schraw \& Moshman, 1995). Cognitive management skills are seen as meaningful in individual learning so that mathematics learning is closer to the ability of cognitive and metacognitive setup and their coordination (Su et al., 2016).

Accordingly, mathematics learning should be a focus on the development of metacognitive regulation to enhance student performance. A low level of student mastery in mathematical concepts is not a new issue, but it still cannot be solved although it has been done in various ways. Most factors are learning activities conducted in the classroom (Willis, 2010). Therefore, the researcher proposes a learning activity to ensure mathematics learning is more fun and can develop metacognitive regulation skills in line with the desire to improve student achievement. In this regard, to strengthen cognitive development, learning must be conducted as a cognitive activity, which is a mind-challenging activity to ensure students' metacognition fully in function (Du Toit \& Kotze, 2009).

Besides that, to achieve the purpose of learning activities that can develop metacognitive regulation is through interactive activities. Active involvement and effective interaction should be examined in selecting the activity. This is because according to Smith \& Mancy (2018), during actual learning student interaction will lead to metacognitive discussion. Metacognitive elements will be the main focus when interacting with a peer during learning. Hence, there is a need for further studies that examine learning activities that can encourage students to metacognitive regulation skills and interactions. When the interaction is well-executed, it will produce effective learning. Dagarin (2005) and Jose (2016) stated that interactions can occur between students with teachers, students with students, students with materials and can also be between students with themselves. Specifically, student interaction with self is individual in nature leading to the formation of self-regulation and this will encourage the learning process. According to Schraw and Moshman (1995), if the situation was forced to act in designing, monitoring and evaluating learning, then the metacognitive regulation development had improved. In the context of the success of mathematical learning, the interaction will ensure that students can express ideas using numbers, symbols, diagrams and so on in all forms of oral, written or visual (Mary,2017; NCTM,2000).

In this context, the researcher proposes a learning activity that can ensure optimum interaction that involves the implementation of entrepreneurial activities in buying and selling. Studies conducted by Palmer and Johansson (2018), Shanklin \& Ehlen (2017), Noor Izzuddin et al., (2014), Ishak et al., (2018), Rayung and Ambatong (2018), Almahry et al., (2018) and Rahmawati (2017) have shown that buying and selling activities can increase focus, active involvement and ability to master the contents of the lesson. According to Palmer and Johansson (2018), entrepreneurship competence will create mathematical competencies leading to thinking skills. Therefore, buying and selling can be a platform to ensure interaction. According to Mantell et al., (2002) and Goh (2010), buying and selling activity is favourable to children and it is a cognitive need and the ability to coordinate problem-solving among children when selling and buying is made into a learning game. Buying and selling is the basic experience that all individuals have. Poh (2000) said that, according to contextual theory, learning will be easier than the experience and knowledge framework that exists in the minds of individuals. In this regard, Schraw and Moshman (1995) and, Nelson and Narens (1990) argued that each individual has the metacognitive experience that will be the basis for constructing a piece of new knowledge. This metacognitive experience will be easier to regulate when there is positive motivation through effective interaction. 
Conceptual Framework of Entrepreneurship, Buying and Selling Activities (EBSA)

The study was aimed at discussing the effectiveness of learning activities through the implementation of entrepreneurship, buying and selling activities (EBSA). Based on the Constructivist Theory, Vygotsky's Social Development Theory and Metacognitive Theory, a learning activity, students' interaction, and metacognitive regulation skills that will be constructed are seen to influence students' learning and their mastery. From constructivism beliefs, learning is one of the processes that students modified their previous skills, experience, and knowledge in order to construct and understand the new concept. Interactions, mediations, and scaffolding become the important elements in Vygotsky's Theory as a social connector to develop the potential and ability of the student in learning. Besides, Metacognitive Theory proposed metacognitive learning strategies to optimise the awareness, regulation, and experience of students in cognitive aspects during the learning process. A conceptual framework was developed to see the relationship between the EBSA as a learning activity, students' interaction and metacognitive regulation skills that will be the variables in this study. According to Sethughes (2013), the basis of buying and selling must include the aspects of place, product, price, and promotion. Next, Rahmawati (2017) explained the five components in the buying and selling game based on marketing activities as i) the role of the student as either the seller or the buyer, ii) the game instructions or the way of how to operate, iii) the product, iv) the process of trading activities and v) discussions. Therefore, the review summarises the construct as a phase in trading activity.

According to Vygotsky's Theory, learning will occur when there is an interaction between students (McLeod, 2018). When interacting, students will develop the individual potential to enhance understanding of the lesson's contents. Through this activity, the students, especially

Table 1: Implementation of trading activity phases and relating it o the learning dimensions

\begin{tabular}{|c|c|c|}
\hline Phases & $\begin{array}{l}\text { Implementation of entrepreneurship, } \\
\text { buying and selling activities (EBSA) }\end{array}$ & Learning Dimensions \\
\hline $\begin{array}{l}\text { Place } \\
\text {-Buyer and seller } \\
\text {-Instructions }\end{array}$ & $\begin{array}{l}\text { i. Buying and selling goals } \\
\text { ii. Determining of roles of buyer or seller } \\
\text { iii. Organising/conducting the activity or } \\
\text { instruction }\end{array}$ & $\begin{array}{l}\text { i. Learning objectives } \\
\text { ii. Students' role in learning } \\
\text { iii. Rules or learning activities are } \\
\quad \text { conducted }\end{array}$ \\
\hline $\begin{array}{l}\text { Product } \\
\text {-Preparing the } \\
\text { product } \\
\text {-preparing the } \\
\text { presentation } \\
\text { needs }\end{array}$ & $\begin{array}{l}\text { i. Sale product } \\
\text { ii. Buyers' needs }\end{array}$ & $\begin{array}{l}\text { i. Learning matters or resources } \\
\text { ii. Presentation materials } \\
\text { iii. Mathematics problem-solving } \\
\text { strategies }\end{array}$ \\
\hline $\begin{array}{l}\text { Price } \\
\text {-Set the price }\end{array}$ & i. Sale price & $\begin{array}{l}\text { i. Learning motivation } \\
\text { ii. Question levels/tasks }\end{array}$ \\
\hline $\begin{array}{l}\text { Promotion } \\
\text {-Trading } \\
\text { activities }\end{array}$ & i. Buying and selling process & $\begin{array}{l}\text { i. Discussion/presentation } \\
\text { ii. Interaction }\end{array}$ \\
\hline
\end{tabular}

Source: Sethughes (2013) and Rahmawati (2017) 
in the process of selling and buying products, will apply the concept of Zone of Proximal Development (ZPD) and More Knowledgeable Other (MKO). There will be a mentoring, tutoring and guiding process. Therefore, buying and selling are scaffolds for interactions and this is in line with the concept of scaffolding based on Vygotsky's Theory (McLeod, 2018). According to the Constructivist Theory, the actual learning experience will ensure that students learn. This is because minds-on and hands-on appreciation will occur and contribute to meaningful learning (Nik Pa, 1999; Poh, 2000).

Through the four phases in trading activities, students will develop metacognitive regulation skills. For example in a place phase, students will plan learning requirements in the role played by either the seller or the buyer. During the course of the product phase, price and promotion will increase students' ability to monitor and evaluate learning through interaction with other students during activities. Students will check the level of understanding and evaluate the learning strategies implemented. This illustrates the role of metacognitive regulation skills in driving learning (Schraw \& Moshman, 1995; Du Toit $\&$ Kotze,1999). At the same time it improves the thinking skills and mathematics problemsolving skills.

Metacognitive Theory illustrates how restructured knowledge is got through metacognitive relationships and selfregulated processes (Schraw \& Moshman,
1995). Metacognitive experts have explained how metacognitive components consist of metacognitive knowledge and metacognitive regulation action affecting individuals as well as learning actions in order to master the subject matter (Menz \& Cindy Xin, 2016; Pantiwati \& Husamah, 2017). In the process of the students are made aware of their abilities and effectively manage the metacognitive aspect of learning that can increase mastery (Cera et al., 2013). An active learning environment that optimises interaction will create learning scenarios through metacognitive development and increase selfdetermination and self-belief of students. The combined results of Constructivist, Vygotsky's and Metacognitive theories will contribute to the achievement of learning objectives and student performance.

\section{Methodology}

The purpose of this present study is to examine the implementation of entrepreneurship, buying and selling activities in mathematics learning which can influence the students' interaction and metacognitive regulation skills that will enhance student engagement, performance, and achievement. Hence, the research questions are being developed to achieve the objectives of this review. The research questions are i.e. how do EBSA in mathematics learning create student's interaction and develop metacognitive regulation skills? What is the impact of EBSA on student mathematics learning?

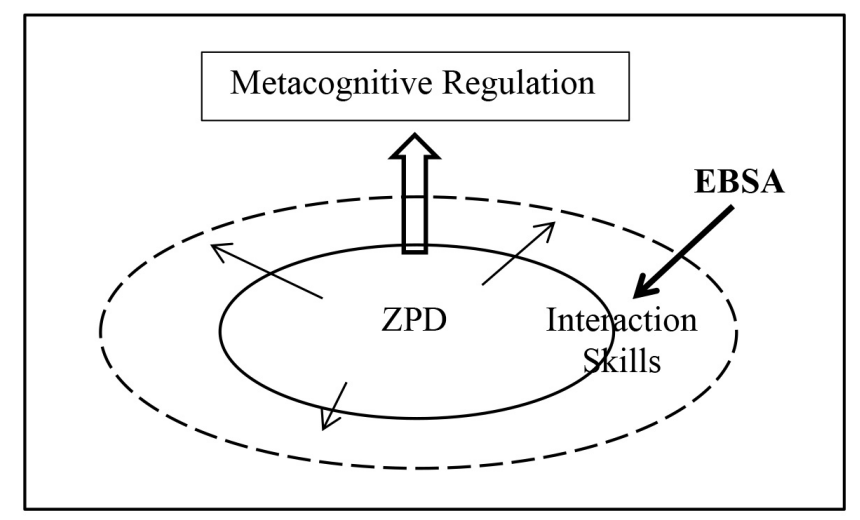

Figure 1: The Conceptual of Mathematics Learning of EBSA 
Furthermore, searching for articles and journals that lead to applications of entrepreneurship education and learning, buying and selling activities, student interactions, metacognition regulation or a combination of these keywords is initiated through databases such as Google Scholar, Researchgate, ERIC, SpringerLink, Elsevier, and some other databases. Journals or articles related to the area of study are selected by first looking at the abstract and if related, the journal contents are viewed more specifically. Literature, data, findings, results, and discussion will be fully referred to. The searching process is the implementation of Preferred Reporting Items for Systematic Reviews and Meta-Analyses (PRISMA) proposed by Moher et al (2009). Eight articles were selected after going through the steps of Identification, Screening, Eligibility and Included. The following table shows the implementation of entrepreneurial skills, buying and selling activities conducted by some researchers in the context of learning.

Table 2: Analysis of Implementation of Buying, Selling and Entrepreneurship Activities in Learning

\begin{tabular}{|c|c|c|c|}
\hline Author(s) & Research Objective(s) & $\begin{array}{l}\text { Learning aspects discussed } \\
\text { through activities }\end{array}$ & $\begin{array}{l}\text { Impact on the } \\
\text { students }\end{array}$ \\
\hline $\begin{array}{l}\text { Hanna Palmer \& Maria } \\
\text { Johansson (2018) } \\
\text { Combining } \\
\text { Entrepreneurship } \\
\text { and Mathematics In } \\
\text { Primary School-What } \\
\text { Happens? } \\
\text { Journal Education } \\
\text { Inquiry, 9(4) }\end{array}$ & $\begin{array}{l}\text { To explore what happens } \\
\text { when entrepreneurship } \\
\text { is integrated into } \\
\text { mathematics lessons }\end{array}$ & $\begin{array}{l}\text { i. Discuss the potential of } \\
\text { combining the teaching } \\
\text { of entrepreneurial } \\
\text { and mathematical } \\
\text { competencies in schools } \\
\text { ii. Implement the } \\
\text { entrepreneurship } \\
\text { principles to solve } \\
\text { mathematics problems } \\
\text { in learning i.e } \\
\text { creativity, ability to take } \\
\text { responsibility, having } \\
\text { courage, and ability to } \\
\text { take initiative }\end{array}$ & 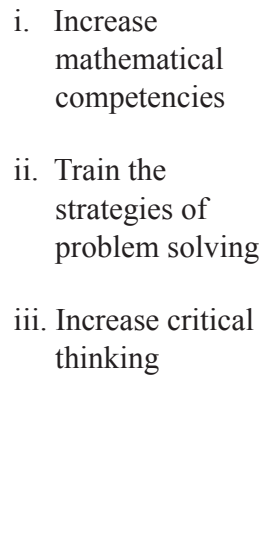 \\
\hline $\begin{array}{l}\text { Eka Rahmawati (2017) } \\
\text { The influence of } \\
\text { buying-selling } \\
\text { Equipment on } \\
\text { Learning Math Results } \\
\text { About Money Class } \\
\text { I in Basic School } \\
\text { (Experimental } \\
\text { Research in The Low } \\
\text { Class). } \\
\text { Published Version } \\
\text { Thesis Online. } \\
\text { Universitas Negeri } \\
\text { Jakarta. }\end{array}$ & $\begin{array}{l}\text { To determine } \\
\text { the difference of } \\
\text { mathematics } \\
\text { learning outcome of } \\
\text { money between students } \\
\text { who follow the learning } \\
\text { with } \\
\text { the activities of buying } \\
\text { and selling games and } \\
\text { students who follow the } \\
\text { learning conventionally }\end{array}$ & $\begin{array}{l}\text { i. Implement of buying and } \\
\text { selling activities during } \\
\text { mathematics learning } \\
\text { ii. Create the principle } \\
\text { of buying and selling } \\
\text { activity i.e targets, } \\
\text { student role plays, } \\
\text { product, buying } \\
\text { and selling process, } \\
\text { discussion setting }\end{array}$ & $\begin{array}{l}\text { i. Impact on } \\
\text { the students' } \\
\text { performance } \\
\text { ii. Increase } \\
\text { students' } \\
\text { problem-solving } \\
\text { skills }\end{array}$ \\
\hline
\end{tabular}




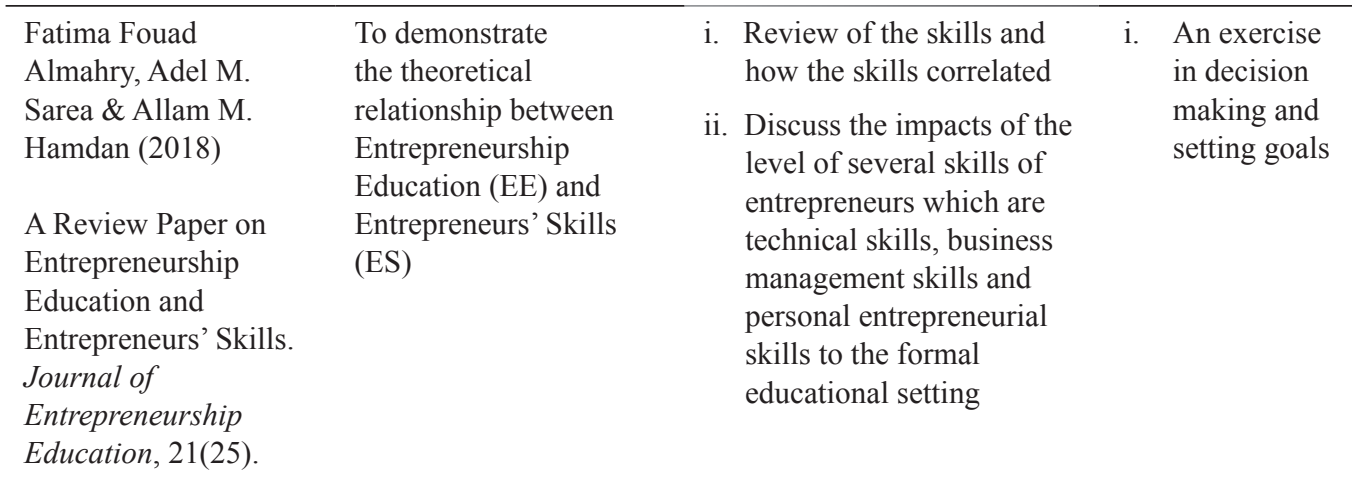

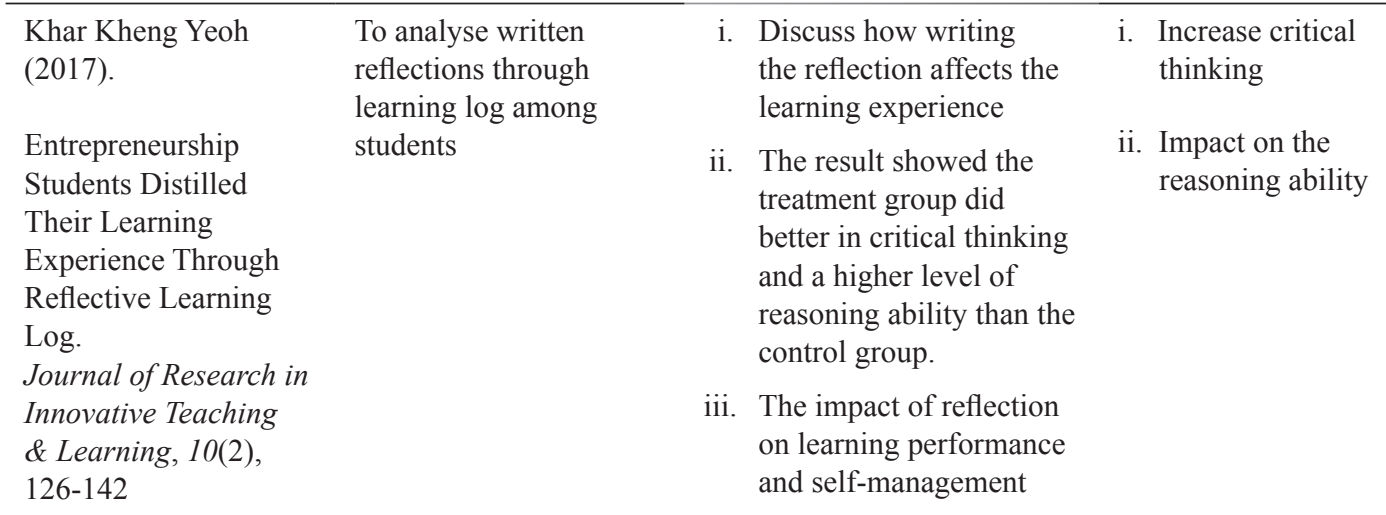

Mario Franco \& Heiko Haase (2009)

Entrepreneurship:

An Organisational

Learning Approach.

Journal of

Small Business

and Enterprise

Development, 16(4), 628-641 i. To shed new light on the interface between learning and entrepreneurship.

ii. To show how entrepreneurship can be studied as a never $\square$ ending, dynamic learning process. i. Describe learning as a crucial factor in entrepreneurial activity.

ii. Discuss a new definition of the entrepreneur (entrepreneur as a learner) and a conceptual model of entrepreneurial learning theory is synthesised.

iii. Setting goal, act to the goal, management, and ability to evaluate the strategies i. To practice the skills

ii. Increase students reasoning and critical thinking

\begin{tabular}{llll}
\hline $\begin{array}{l}\text { Sanchez-Garcia \& Jose } \\
\text { Carlos (2011) }\end{array}$ & $\begin{array}{l}\text { To test the effect of } \\
\text { entrepreneurship } \\
\text { education programmes } \\
\text { on the entrepreneurial } \\
\text { competencies }\end{array}$ & $\begin{array}{l}\text { i. } \\
\begin{array}{l}\text { Discuss the impact of } \\
\text { entrepreneurship activities } \\
\text { on students' learning }\end{array}\end{array}$ & $\begin{array}{l}\text { i. } \\
\begin{array}{l}\text { University Training } \\
\text { for Entrepreneurial } \\
\text { Competencies: Its }\end{array}\end{array}$ \\
$\begin{array}{l}\text { Impact on Intention of } \\
\text { Venture Creation } \\
\text { International } \\
\text { Entrepreneurship and } \\
\text { Management Journal, } \\
\text { 7(2), 239-254. }\end{array}$ & $\begin{array}{l}\text { ii. Responsibility for the } \\
\text { learning process }\end{array}$ & $\begin{array}{l}\text { ii. Impact on the } \\
\text { intention of } \\
\text { students }\end{array}$ \\
\end{tabular}




\begin{tabular}{|c|c|c|c|c|}
\hline $\begin{array}{l}\text { Martha Christianti, } \\
\text { Nur Cholimah, \& } \\
\text { Bambang Suprayitno } \\
\text { (2015) } \\
\text { Development of } \\
\text { Entrepreneurship } \\
\text { Learning Model for } \\
\text { Early Childhood. } \\
\text { Asia Pacific Journal } \\
\text { of Multidisciplinary } \\
\text { Research,3(3) }\end{array}$ & $\begin{array}{l}\text { i. To explore } \\
\text { how learning } \\
\text { entrepreneurship } \\
\text { was done in early } \\
\text { childhood } \\
\text { ii. To know whether } \\
\text { parents, teachers, and } \\
\text { principals support } \\
\text { entrepreneurship } \\
\text { learning } \\
\text { iii. To identify what } \\
\text { kind of values of } \\
\text { entrepreneurship can } \\
\text { be developed for } \\
\text { early childhood }\end{array}$ & 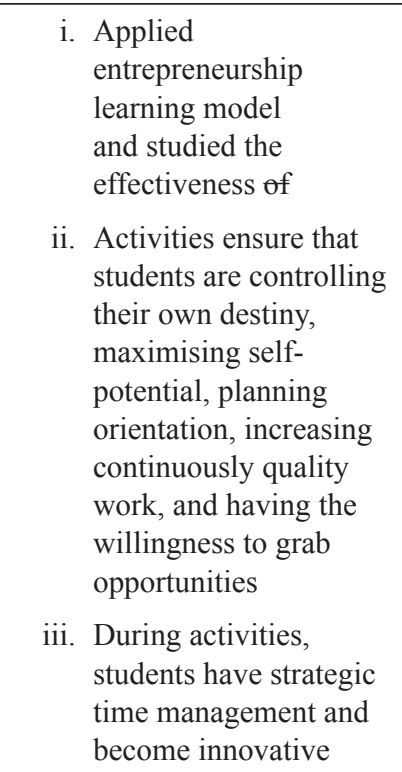 & ii. & $\begin{array}{l}\text { Develop self- } \\
\text { confidence } \\
\text { Become } \\
\text { creative and } \\
\text { innovative }\end{array}$ \\
\hline $\begin{array}{l}\text { Mohd Nasir Rayong \& } \\
\text { Abdul Said Ambotang } \\
\text { (2016) } \\
\text { Relationship Between } \\
\text { Entrepreneurship Skill, } \\
\text { Management Skill and } \\
\text { Life-Long Learning } \\
\text { Towards Critical } \\
\text { Thinking Skill Among } \\
\text { Form } 6 \text { Students } \\
\text { Jurnal Kinabalu. }\end{array}$ & $\begin{array}{l}\text { To determine the direct } \\
\text { and indirect relationship } \\
\text { of the factors of } \\
\text { imagination, self- } \\
\text { motivation and the } \\
\text { imagination capability } \\
\text { towards thinking skills } \\
\text { among } \\
\text { Form Six students }\end{array}$ & $\begin{array}{l}\text { i. Discuss the influence of } \\
\text { entrepreneurship skill on } \\
\text { the students thinking skill } \\
\text { ii. Awareness of the learning } \\
\text { process } \\
\text { iii. Choose the right strategies } \\
\text { to solve the problem }\end{array}$ & iii. & $\begin{array}{l}\text { Practice critical } \\
\text { thinking } \\
\text { Develop } \\
\text { thinking and } \\
\text { management } \\
\text { skills } \\
\text { Impact on the } \\
\text { student s' self- } \\
\text { determination } \\
\text { and self- } \\
\text { management }\end{array}$ \\
\hline
\end{tabular}

It can be concluded that in the course of conducting EBSA activities, the skills in managing the sale and entrepreneurship will be practiced. Based on the above, the summary of the skills are:

i. Character and perspective skills, based on the roles and responsibilities of either the seller or buyer

ii. Planning and placing goals skills, involving requirements, needs, time and strategy

iii. Managing trading activities skills, involving the selection of appropriate strategies and ways of action to achieve the goals iv. Contingency and initiative skills which involve creativity and flexibility to ensure accuracy and quality

v. Collaborative skills which involve interaction ability, clarity of presentation

vi. Reflection skills involve the assessment of the entire process and the findings

The application of these skills will lead to increased thinking and problem-solving skills. In the context of learning, the skills are the basis of self-regulation and are seen as inclined to the development of metacognitive regulation skills. The next analysis table will explain the metacognitive regulation skills in learning. 
Table 3: Analysis of Components of Metacognitive Regulation and Related to the Students' Skills

\begin{tabular}{|c|c|c|}
\hline $\begin{array}{l}\text { Metacognitive } \\
\text { Regulation } \\
\text { Components }\end{array}$ & Student's Skills & References \\
\hline Planning & $\begin{array}{l}\text { i. Study how to learn about topics, } \\
\text { laying goals } \\
\text { ii. Know the source of information } \\
\text { iii. Set some of the strategies that can } \\
\text { be used } \\
\text { iv. Selecting appropriate and accurate } \\
\text { strategies } \\
\text { v. Design the assignment/task and the } \\
\text { time required for the assignment/task }\end{array}$ & $\begin{array}{l}\text { Schraw \& Moshman (1995), Smith } \\
\text { (2013), Cera et al., (2013), Tony } \\
\text { Karnain et al., (2014), Amin \& } \\
\text { Sukestiyarno (2015), Du Toit \& Du } \\
\text { Toit (2013) } \\
\text { Menz \& Cindy Xin (2016), } \\
\text { Ackerman \& Leiser (2014) }\end{array}$ \\
\hline Monitoring & $\begin{array}{l}\text { i. Manage time to understand the } \\
\text { information } \\
\text { ii. Take time to implement strategies } \\
\text { iii. Perform selected strategies/ } \\
\text { operations } \\
\text { iv. Focus on the more important thing, } \\
\text { what needs to be done first } \\
\text { v. Implement an alternative way if the } \\
\text { previous way is ineffective } \\
\text { vi. Track on relevant matters which are } \\
\text { important to remember }\end{array}$ & $\begin{array}{l}\text { Smith \& Mancy (2018) } \\
\text { Amin \& Sukestiyarno (2015), } \\
\text { Adnan \& Arsad Bahri (2018), } \\
\text { Hasbullah (2015), Du Toit \& Du } \\
\text { Toit (2013) }\end{array}$ \\
\hline Evaluation & $\begin{array}{l}\text { i. Reflection of objective achievement } \\
\text { ii. Evaluate the level of accuracy of the } \\
\text { assignment/task } \\
\text { iii. Evaluate the level of achievement / } \\
\text { how to answer the question is better } \\
\text { than before } \\
\text { iv. Make sure new knowledge is in line } \\
\text { with the original knowledge }\end{array}$ & $\begin{array}{l}\text { Schraw \& Moshman (1995), Amin } \\
\& \text { Sukestiyarno (2015), Du Toit \& } \\
\text { Du Toit (2013), Tony Karnain et al., } \\
\text { (2014), Hasbullah (2015), Suriyon } \\
\text { et al., (2013) }\end{array}$ \\
\hline
\end{tabular}

The metacognitive regulation component i.e planning, monitoring, and evaluation will be indicators in the learning process. This regulation will influence the work and action of the students in their learning that will affect mastery.

\section{Results and Discussion}

The focus of this review is to answer the question of how entrepreneurial activity can conceptually develop metacognitive regulation skills of students in solving mathematics problems and ultimately master the mathematics concepts. Then it discussed the impact of an activity on the students and the learning of mathematics. In order to gain a link between entrepreneurial skills and buying and selling activities with metacognitive regulation skills, the researcher provides Table 4 , the correlations and a summary of Table 2 and Table 3. 
Table 4: A meta-analysis of the relationship between entrepreneurial skills and metacognitive regulation skills

\begin{tabular}{|c|c|c|c|}
\hline $\begin{array}{l}\text { Entrepreneurial } \\
\text { Skills (EBSA's } \\
\text { Phases) }\end{array}$ & Descriptions & $\begin{array}{c}\text { Relevance to } \\
\text { Metacognitive } \\
\text { Regulation Skills }\end{array}$ & Impact on the students \\
\hline $\begin{array}{l}\text { Character and } \\
\text { perspective skills }\end{array}$ & $\begin{array}{l}\text { i. Responsibility to the } \\
\text { characters either seller } \\
\text { or buyer } \\
\text { ii. Mind setting } \\
\text { according to the } \\
\text { perspective of } \\
\text { salesperson or } \\
\text { customer } \\
\text { iii. Know what to do }\end{array}$ & $\begin{array}{l}\text { Planning } \\
\text { - plan, adhere to } \\
\text { learning and goals }\end{array}$ & 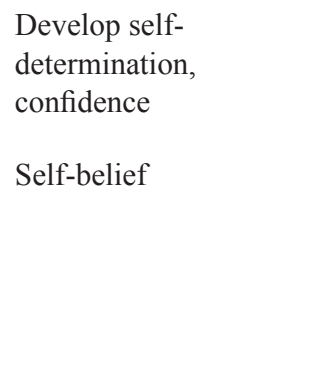 \\
\hline $\begin{array}{l}\text { Planning and placing } \\
\text { goals skills }\end{array}$ & $\begin{array}{l}\text { i. Always review the } \\
\text { requirements and needs } \\
\text { ii. Plan time, cost and } \\
\text { material } \\
\text { iii. Target and goals to be } \\
\text { achieved } \\
\text { iv. Manage available } \\
\text { opportunities with skill }\end{array}$ & $\begin{array}{l}\text { Planning } \\
\text { - Discover the aims, } \\
\text { goals } \\
\text { - Manage action } \\
\text { - Manage time }\end{array}$ & $\begin{array}{l}\text { Develop critical } \\
\text { thinking } \\
\text { Reasoning } \\
\text { Quickly choose a } \\
\text { solutions strategy }\end{array}$ \\
\hline $\begin{array}{l}\text { Managing trading } \\
\text { activities skills }\end{array}$ & $\begin{array}{l}\text { i. Know when and } \\
\text { where according to } \\
\text { needs } \\
\text { ii. High communication } \\
\text { skills } \\
\text { iii. Can predict risk } \\
\text { iv. Monitor the current } \\
\text { level of achievement }\end{array}$ & $\begin{array}{l}\text { Planning } \\
\text { - Define strategy } \\
\text { - Predict what will } \\
\text { happen } \\
\text { Monitoring } \\
\text { - Set the time } \\
\text { - Manage time } \\
\text { - Use application } \\
\text { strategy } \\
\text { Evaluating } \\
\text { - Assess current } \\
\text { achievement }\end{array}$ & $\begin{array}{l}\text { Increase communication } \\
\text { skill } \\
\text { The problem-solving } \\
\text { exercises } \\
\text { increase problem- } \\
\text { solving skill }\end{array}$ \\
\hline
\end{tabular}




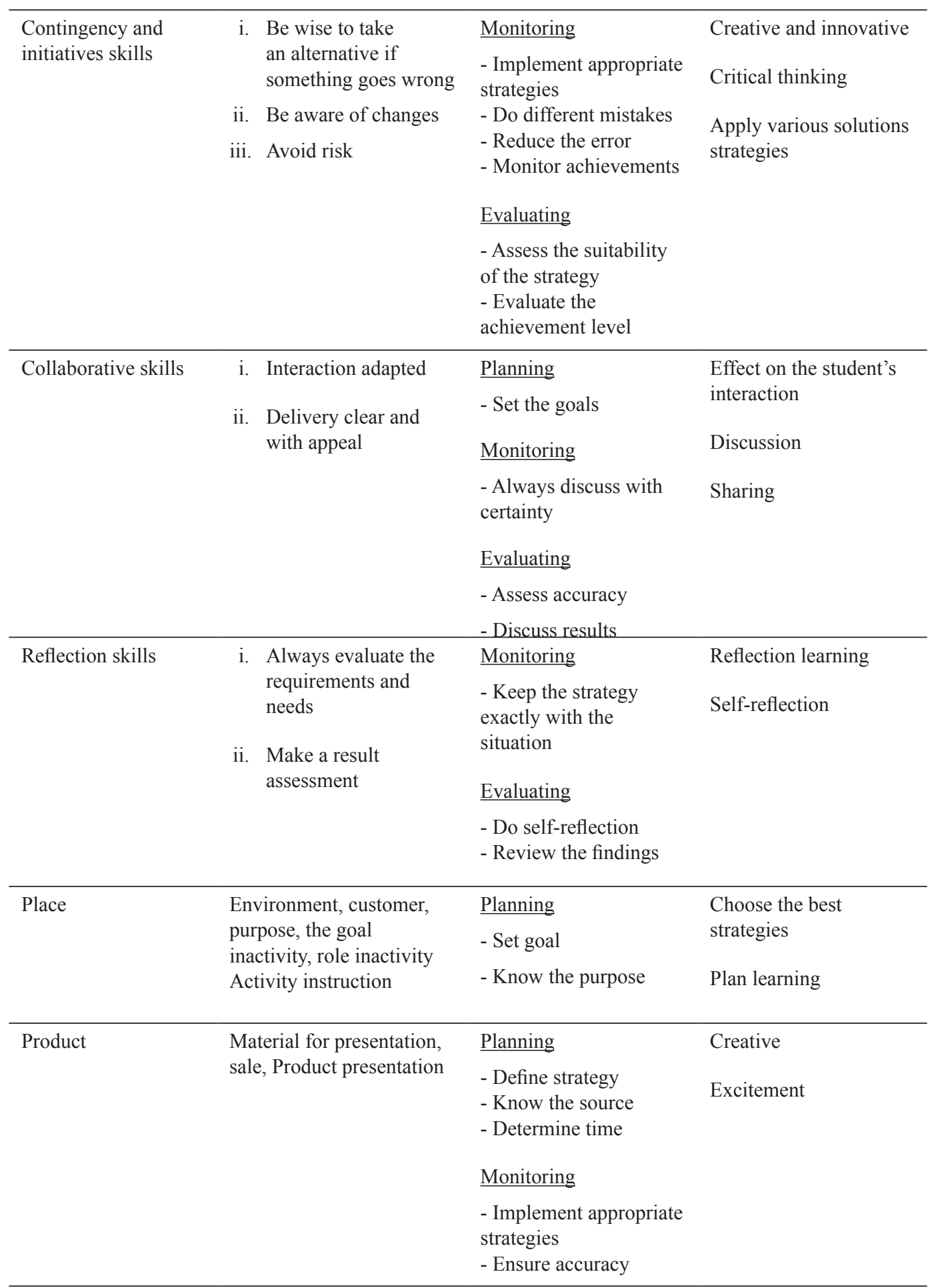




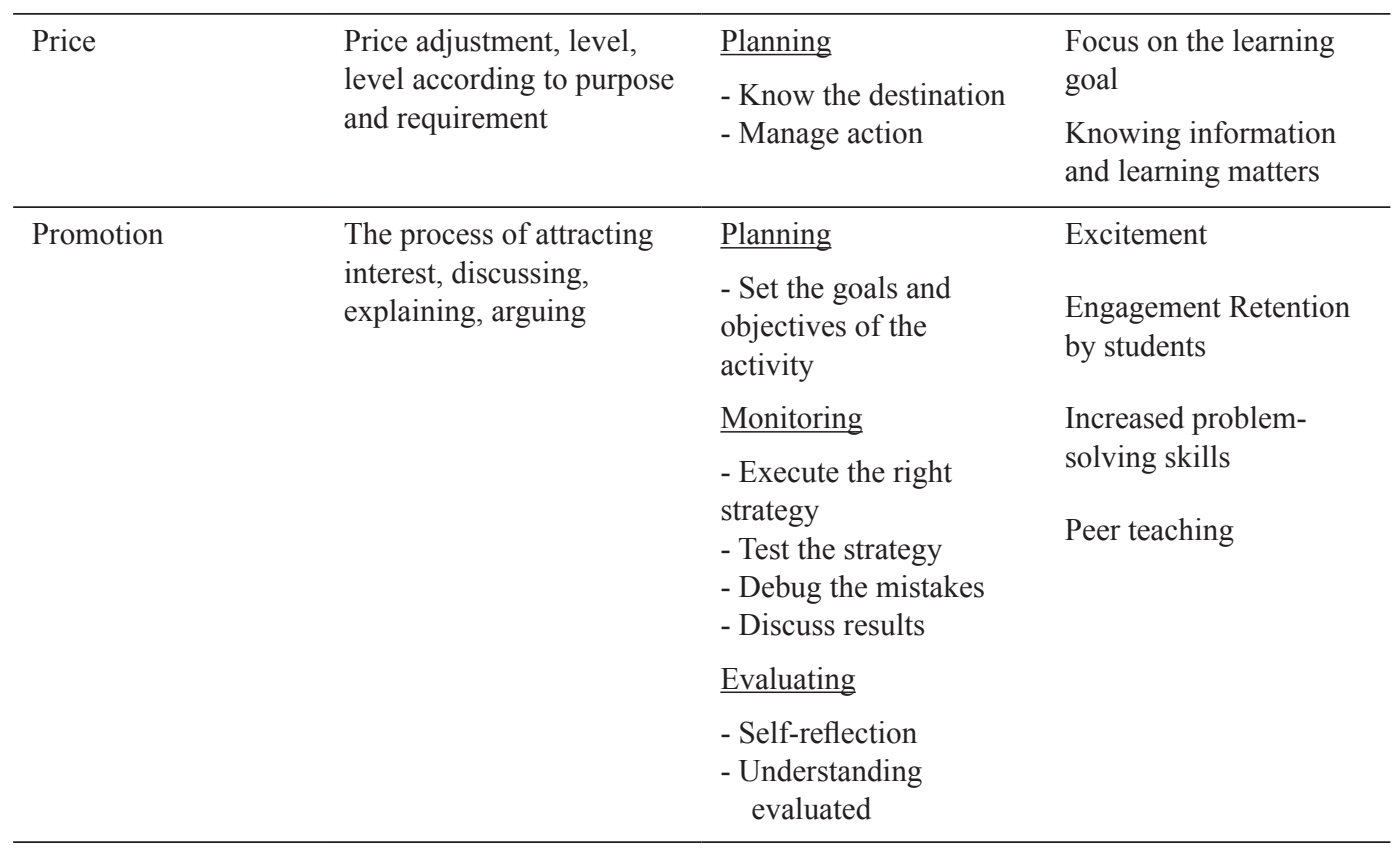

Mantell et al., (2002) stated that buying and selling is a person's cognitive need and is the most basic learning of recognising numbers. Individual cognition can be developed in line with the buying and selling activities. During mathematics learning, when cognitive changes occur, then metacognitive regulation skills are also evolving and this situation will have an influence on students' mastery. Studies by Sanchez-Garcia \& Carlos (2011), Christianti et al., (2015), Rayung \& Ambotang (2016) and Rahmawati (2017) reported that cognitive needs lead to changes in self-esteem and selfmanagement for the better. Entrepreneurship is also one of the examples of individual social skills and this experience is needed as a learning base (Jaslinah, 2012). Almahry et al., (2018), Khar et al., (2017), and Franco and Haase, (2009) explained in their study that through the activities of buying and selling, students' communication improves and affects the mathematics learning process. These collaborative skills will enhance students' metacognitive experiences. This experience will form a temporary framework and will be updated with new experiences during learning process.
According to Palmer and Johannson, (2018), and Rahmawati (2017) entrepreneurship competence involves thinking skills, i.e. skills to analyse needs, comparative differences, and so on to buy or sell something. This skill when applied in the classroom along with mathematics problem solving will train the students' metacognitive regulation skills. The ability to coordinate problem-solving in learning by way of entrepreneurship and playing the roles of seller or buyer will have an impact on mathematics learning by developing metacognitive regulation skills. According to Goh (2010) experience and needs as a seller or buyer is are effective because they test how to think, organise, manage and take initiative or alternative to solve the problem during an activity and learning mathematics. Researchers such as Almahry et al., (2018), Khar et al., (2017), Franco and Haase, (2009), Christianti et al., (2015), and, Rayung and Ambotang, (2016) reported that entrepreneurial, buying and selling activities can enhance student thinking competencies. This indicates that many researchers involved in this study support that metacognitive regulation skills, creative and critical thinking skills develop 
simultaneously while doing these activities. In addition, through entrepreneurial skills, buying and selling activities, effective interaction is highly encouraged and this will contribute to the growing aspects of metacognitive regulation skills of students as explained by Adnan and Arsad Bahri, (2018) that is, the students' metacognitive regulation skills are very influential when they can be created during active learning. In active learning, interaction can encourage students to give and share ideas and develop positive behaviours to learning such as concentration, excitement and so on. In the interaction process, when students are aware of the level of previous knowledge, they will manage their thinking by planning, monitoring and evaluating current learning (Franco \& Haase, 2009; Khar et al., 2017; Almahry et al., 2018). The real interaction is when students can communicate with their minds through the process of self-metacognition. This process will contribute to the mastery of mathematics. This has been discussed and evidenced in studies that investigated on how metacognition and student achievement correlated (Du Toit \& Kotze, 2009; Hasbullah, 2015; Amin \& Sukestiyarno, 2015; Menz \& Cindy Xin, 2016; Ibrahim \& Iksan, 2017; Herlina et al., 2018).

\section{Conclusion}

The present study reviewed the implementation of entrepreneurship, buying and selling activities as a study input targeted at mathematics learning to see the output. In summary, this study can illustrate that the implementation of EBSA can alter the scenario and give re-branding to learning. The contribution to this study was to provide knowledge on the influence of metacognitive regulation and interaction skills in pursuing mathematics learning. Additionally, this study also contributes knowledge of mathematics learning directly. Mathematics is a unique, abstract and complex knowledge that requires mental adaptation and various skills. This study reinforces the statement that learning mathematics requires the mathematical medium itself. An example is a trading activity, which is also one of the areas of mathematics. Thinking mathematically is the best way to learn mathematics. This study has also clarified the concept of transversal competence and multiliteracies, which combine various competencies to explore other competencies. It also shows a combination of strategies and methods of learning. So, to ensure that the knowledge continues, further studies can be conducted by focusing on other skills to apply in mathematics learning, for example, creating and designing skills. Besides that, this study can also be further developed by producing more specific teaching models or developing modules, aids, tools, mobile apps, and software.

\section{Acknowledgements}

This paper is part of a dissertation which was submitted as partial fulfilment to meet requirements for the degree of Master of Philosophy at Universiti Teknologi Malaysia.

Abbreviations: EBSA: Entrepreneurship, buying and selling activities

\section{References}

Ackerman, R., \& Leiser, D. (2014). The effect of concrete supplements on metacognitive regulation during learning and open-book test taking. British Journal of Educational Psychology, 84(2), 329-348.

Adnan \& Arsad Bahri (2018). Beyond effective teaching: Enhancing students' metacognitive skill through guided inquiry. Journal of Physics, Conference Series, 954. 012022. Doi :10.1088/17426596/954/1/012022.

Almahry, F. F., Sarea, A. M. \& Hamdan, A. M. (2018). A review paper on entrepreneurship education and entrepreneurs' skills. Journal of Entrepreneurship Education, 21(25), 1-7.

Amin, I. \& Sukestiyarno, Y.L. (2015). Analysis metacognitive skills on learning mathematics in high school. International Journal of Education and Research, 3(3), 213-222. 
Cera, R., Mancini, M. \& Antonietti, A. (2013). Relationship between metacognition, selfefficacy and self-regulation in learning. ECPS-Journal, 7. 116-141. Doi: 10.7358/ ecps-2013-007-cera.

Chris, O. (2015).Teaching Maths In The $21^{\text {st }}$ Century. Changing the Focus from Calculations to Critical Thinking. http:// blog.learningbird.com.

Dagarin, M. (2005). Classroom interaction and communication strategies in learning english as a foreign language. English language and Literature Teaching, 1(2), 127-139 Doi: 10.4312/elope.1.1-2.127-139.

Du Toit, S. D. \& Du Toit, G. F. (2013). Learner metacognition and mathematics achievement during problem-solving in a mathematics classroom. TD the Journal for Trans disciplinary Research in Southern Africa, 9(3), (Special edition), 505-518.

Du Toit, S. \& Kotze, G. (2009). Metacognitive strategies in the teaching and learning of mathematics. Pythagoras, 70, 57-67.

Franco, M.\&Haase,H.(2009). Entrepreneurship: An organisational learning approach. Journal of Small Business and Enterprise Development, 16(4), 628-641.

Garcia, S. \& Carlos, J. (2011). University training for entrepreneurial competencies: It's Impact on intention of venture creation. International Entrepreneurship and Management Journal, 7(2), 239-254.

Goh, S.S. (2010). Impact of "Brain Gym" Activities on Preschool Children's Cognitive Development. Master of Education. Universiti Sains Malaysia.

Herlina Ahmad, Febryanti, Fatimah \& Muthmainnah (2018). Description of student's metacognitive ability in understanding and solving mathematics problem. 4th International Conference on Operational Research (InteriOR) IOP Conf. Series: Materials Science and Engineering, 300, 012-048. Doi:10.1088/1757899X/300/1/012048.
Ibrahim, N. H. \& Iksan, Z. H. (2017). Metacognitive strategy and high level thinking skills in teaching and learning process. Proceeding of Education Symposium at Personalized: An-Nur Brochure Perspective (SPRiN2017).

Ishak, S., Omar, A. R., Al Bakri, F. M. \& Osman, L. H. (2018). Learning practices and its impact on creation of knowledge and business skills in the generation of $\mathrm{Z}$. Malaysian Journal of Society and Space, 14(1), 15-28.

Khar, K. Y.(2017). Entrepreneurship students distilled their learning experience through reflective learning log. Journal of Research in Innovative Teaching \& Learning, 10(2), 126-142.

Mantel, S. P., Pullins, E. B., Reid, D. A. \& Buehrer, R. E. (2002). A realistic sales experiences: Providing feedback by integrating buying selling and managing experiences. The Journal of Personal Selling and Sales Management, 22(1), 3340.

Mary, E. P.(2017). How math education can catch up to the $21^{\text {st }}$ century. Colorado State University. http://theconversation.com.

McLeod, S. A. (2018). Lev Vygotsky. https:// www.simplypsychology.org/vygotsky.html.

Menz, P. \& Cindy, X. (2016). Making students' metacognitive knowledge visible through reflective writing in a mathematics-forteachers course. Collected Essays on Learning and Teaching, Vol. IX. Simon Fraser University.

Moher, D., Liberati, A., Tetzlaff, J. \& Altman, D. G. (2009). Preferred reporting items for systematic reviews and meta-analyses: The PRISMA statement. PLoS Med, 6(7), e1000097. Doi:10.1371/journal. pmed.1000097.

Moos, D. C. \& Ringdal, A. (2012). Selfregulated learning in the classroom: a literature review on the teacher's role. Education Research International, 2012, 1-15 Doi:10.1155/2012/423284. 
National Council of Teachers of Mathematics (2000a). Professional Standards for Teaching Mathematics. New York: NCTM.

National Council of Teachers of Mathematics (2000b). Principles and Standards for School Mathematics. Reston, VA: NCTM.

Nelson, T. O. \& Narens, L. (1990). Metamemory: A theoretical framework and new findings. Psychology of Learning and Motivation, 26, 125-173.

Nik Pa, N. A. (1999). Radical Constructivism Approach in Mathematics Education. Publisher University of Malaya. Kuala Lumpur, Malaysia.

Palmer, H. \& Johansson, M. (2018). Combining entrepreneurship and mathematics in primary school-what happens? Journal Education Inquiry, 9(4). 331-346. https:// doi.org/10.1080/20004508.2018.1461497.

Pantiwati, Y. \& Husamah (2017). Self and peer assessments in active learning model to increase metacognitive awareness and cognitive abilities. International Journal of Instruction, 10(4), 185-202. https://doi. org/10.12973/iji.2017.10411a.

Poh, S.H. (2000). Teaching Education Series, Science Pedagogy 2: Teaching Strategies for Teaching Science. Kumpulan Budiman Sdn. Bhd. Subang Jaya, Selangor, Malaysia.

Pokhrel, T. R (2018). Activity based mathematics instruction: Experiences in addressing the 21st-century skills. Journal of Mathematics Education, 11(1), 46-61.

Rahmawati, E. (2017). The Influence of Buy Selling Equipment on the Learning Math Results about Money Class Iii Basic School (Experimental Research in the Low Class). Other Thesis, Published Version. Universitas Negeri Jakarta. http://repository. unj.ac.id/230/.

Rayung, M. N. \& Ambotang, A. S. (2016) Relationship between entrepreneurship skill, management skill and life-long learning towards critical thinking skill among form 6 students. Jurnal Kinabalu, 22(2016), 1-20.
Schraw, G. \& Moshman, D. (1995). Metacognitive Theories. Educational Psychology Papers and Publications. 40. http://digitalcommons.unl.edu/ edpsychpapers/40.

Sethughes (2013). Principles of Marketing - Basic Concepts and Fundamentals. https://toughnickel.com/industries/ PrinciplesofMarketingPart1BasicConcept sandFundamentals.

Smith, J. M \& Mancy, R. (2018). Exploring the relationship between metacognitive and collaborative talk during group mathematical problem-solving - what do we mean by collaborative metacognition? Research in Mathematics Education, 20(1), 14-36.

Shanklin, S. B. \& Ehlen, C.R. (2017). Extending the use and effectiveness of the monopoly ${ }^{\circledR}$ board game as an in-class economic simulation in the introductory financial accounting course. American Journal of Business Education - Second Quarter 2017, 10(2),75-80.

Su, H. F., Ricci, F. A., \& Mnatsakanian, M. (2016). Mathematical teaching strategies: Pathways to critical thinking and metacognition. Journal of Research in Education and Science (IJRES), 2(1), 190200.

Suriyon, A., Inprasitha, M. \& Sangaroon, K.(2013). Students' metacognitive strategies in the mathematics classroom using open approach. Psychology, 4(7), 585-591.

Tony Karnain, Md Nor Bakar, Seyed Yaser Mousavi Siamakani, Hossein Mohammadikia, \& Muhammad Candra (2014). Exploring the metacognitive skills of secondary school students' use during problem posing. Jurnal Teknologi (Social Sciences), 67(1), 27-32.

Willis, J. (2010). Building Math Positivity. George Lucas Educational Foundation. https://www.edutopia.org/blog/buildingmath-positivity 